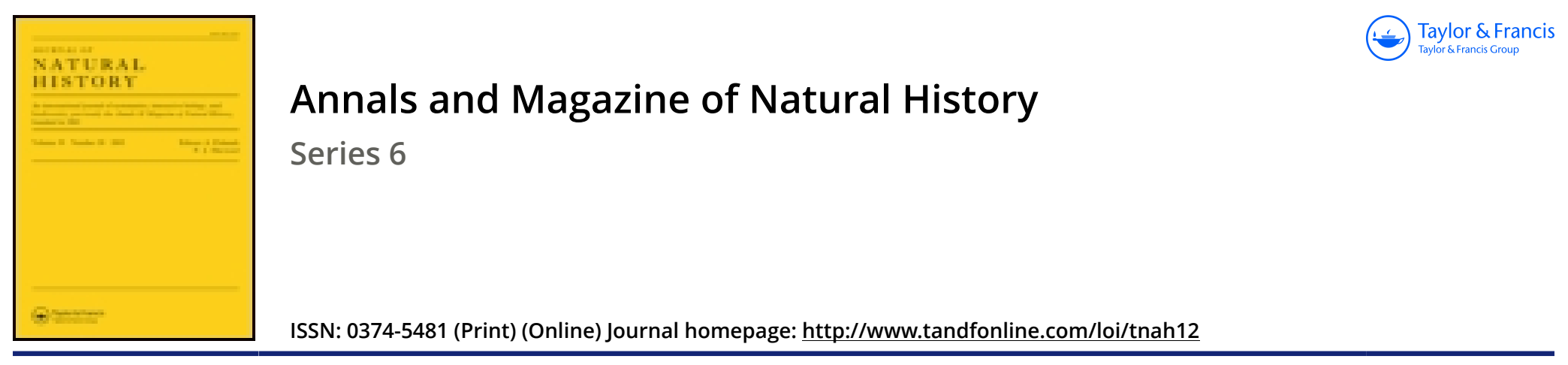

\title{
XL.-Natural History notes from H.M. Indian Marine survey steamer 'Investigator,' Lieut. G. S. Gunn, R.N., Commanding.-Series II., No. 5. On the Bathybial fishes collected during the season of 1891-92
}

\section{A. Alcock M.B.}

To cite this article: A. Alcock M.B. (1892) XL.-Natural History notes from H.M. Indian Marine survey steamer 'Investigator,' Lieut. G. S. Gunn, R.N., Commanding.-Series II., No. 5. On the Bathybial fishes collected during the season of 1891-92, Annals and Magazine of Natural History, 10:59, 345-365, DOI: 10.1080/00222939208677427

To link to this article: http://dx.doi.org/10.1080/00222939208677427

\section{Published online: 02 Oct 2009.}

\section{Submit your article to this journal $\widetilde{ }$}

Џ Article views: 4

Q View related articles ¿

4 Citing articles: 2 View citing articles 준 


\title{
THE ANNALS
}

AND

\section{MAGAZINE OF NATURAL HISTORY.}

\author{
[SIXTH SERIES.]
}

No. 59. NOVEMBER 1892.

XL.-Natural History Notes from H. Y. Indian Marine Survey Steamer 'Investigator,' Lieut. G. S. Gunn, R.N., commanding.-Series II., No. 5. On the Bathybial Fishes collected during the Season of 1891-92. By A. A LCock, M.B., Surgeon-Naturalist to the Survey.

\section{[Plate XVIII.]}

On fifteen occasions during the course of her recent surveys of the Laccadive Islands and Coromandel coast the "Investigator' carried out successful trawlings in the deep-sea. The tishes described in this paper were taken on twelve of these occasions, and as a preface to the descriptions of the tishes a brief notice of the principal features of the stations at which they were trawled may be given.

\section{§ 1. A brief notice of the Trawling-Stations.}

Station 121.-Laccadive Sea, lat. $14^{\circ} 35^{\prime} 15^{\prime \prime}$ N., long. $72^{\circ} 02^{\prime} 37^{\prime \prime}$ E., 1140 fathoms ; bottom grey calcareous (coral) ooze; bottom temperature $37^{\circ} .5$ Fahr. A poor ground, except in Holothurians, of which some good specimens of Benthodytes and Psychropotes were taken, the gelatinous dorsal appendage of the latter being larger than the body of the animal itself.

Station 122.-Laccadive Sea, lat. $12^{\circ} 05^{\prime} 55^{\prime \prime}$ N., long. Ann. \& Mag. N. Hist. Ser. 6. Vol. x. 
$71^{\circ} 33^{\prime} 30^{\prime \prime}$ E., $865-880$ fathoms ; bottom Globigerina-ooze ; bottom temperature $40^{\circ} \mathrm{Fahr}$. The haul here was a good one; perhaps the most interesting capture was that of a small Terebratuloid Brachiopod with a branching peduncle forming a tuft which is so firmly anchored among foraminifera shells that masses of the latter still adhere to the detached specimens.

Station 126.-Laccadive Sea, lat. $8^{\circ} 49^{\prime}$ N., long. $73^{\circ} 18^{\prime}$ $45^{\prime \prime}$ E., 1370 fathoms; bottom calcareous (coral) ooze; bottom temperature $36^{\circ} \mathrm{Fahr}$.

Station 127.-Laccadive Sea, lat. $8^{\circ} 19^{\prime}$ N., long. $73^{\circ} 11^{\prime}$ E., 1200 fathoms; bottom coral-ooze with many shells of foraminifera. This ground, close by the island of Minnikoy, was a very good one, especially for "Asteroidea and Ophiuroidea, of which many specimens, of ten species, were taken.

Station 128.-Gulf of Manaar, lat. $6^{\circ} 58^{\prime}$ N., long. $77^{\circ} 26^{\prime}$ $50^{\prime \prime}$ E., 902 fathoms; bottom green mud, with very numerous chitinous annelid tubes, stout and over 6 inches long, many with their living occupants.

Station 129.-Bay of Bengal, lat. $16^{\circ} 41^{\prime}$ N., long. $82^{\circ} 33^{\prime}$ $45^{\prime \prime}$ E., 270 fathoms; bottom a red-brown ooze from the River Godávari. Besides the Macruri and Coloconger and Nettastoma, which are characteristic of muddy stations at this depth in the Bay of Bengal, and besides the equally characteristic mollusks Nucula and Amussium, not very much was taken.

Station 130.-Bay of Bengal, lat. $16^{\circ} 20^{\prime} 40^{\prime \prime}$ N., long. $82^{\circ} 19^{\prime} 15^{\prime \prime}$ E., 281-258 fathoms; bottom river-borne mud, bottom temperature $51^{\circ} \mathrm{Fahr}$.

Station 131.-Bay of Bengal, lat. $16^{\circ} 01^{\prime}$ N., long. $81^{\circ} 25^{\prime}$ E., 410 fathoms ; bottom the same river-mud; bottom temperature $45^{\circ} .5 \mathrm{Fahr}$. Besides the characteristic formsMacrurus investigatoris, Nettastoma taniola, \&c.-many specimens of a species of Phormosoma, and almost as many of a fine large species of Ophiopeza, were taken, as well as nine fine specimens of Flabellum laciniatum, Phil.

Station 132.-Bay of Bengal, lat. $12^{\circ} 50^{\prime} \mathrm{N}$., long. $81^{\circ} 30^{t}$ E., 475 fathoms ; bottom a red-brown ooze brought down by the River Kistna; bottom temperature $45^{\circ} .5$ Fahr. Most worthy of mention are the fine Spatangoids (Lovenia or a close ally), of which more than a score of fine specimens were 
taken. Several specimens of Flabellum laciniatum, Phil., also occurred.

Station 133.-Bay of Bengal, lat. $15^{\circ} 43^{\prime} 30^{\prime \prime}$ N., long. $81^{\circ} 19^{\prime} 30^{\prime \prime}$ E., 678 fathoms; bottom brown mud hardening into clay ; bottom temperature $42^{\circ} \mathrm{Fahr}$. Over one hundred fine specimens of a species of Phormosoma were taken, and many specimens of Flabellum japonicum, Moseley, and Bathyactis symmetrica, Pourtalès.

Station 134.-Bay of Bengal, about 30 miles S.W. of the last, 753 fathoms; bottom brown mud hardening into clay; bottom temperature $41^{\circ} \cdot 2$ Fahr. Phormosomas, Spatangoids, and Flabellum corals were of noteworthy occurrence.

Station 135.-OOff Konkan coast, lat. $15^{\circ} 29^{\prime}$ N., long. $72^{\circ} 41^{\prime}$ E., 559 fathoms; bottom green mud with a good many foraminifera shells; bottom temperature $47^{\circ}$ Fahrr. Here the most interesting captures were several specimens of Brisinga, a stalked Crinoid, and two individuals of a Sipunculus with ova tloating free in the body-cavity. In a second haul, close by, some dead branches of a Lophohelia were dredged-the tirst Oculinoid coral reported from the coasts of India.

§2. Descriptions of the Fishes, with some brief notes on the Ova and on some peculiarities of the Enteric Mucosa of certain Deep-sea Fishes.

The bathybial fishes obtained during the season of 1891-92 number twenty-seven species, which include eight new to science. Of types not hitherto recorded from India there must here be noticed Xenodermichthys, Leptoderma, Uroconger, and, if the discovery of an empty egg-capsule be accepted as sufficient evidence, Chimcera.

\section{Order CHONDROPTERYGII.}

Suborder HOLOCEPHALA.

Family Chimæridæ.

Chimera, Linn.

1. Chimeera monstrosa, Linn.?

From Station 131, 410 fathoms, there comes an empty eggcapsule in very good preservation, which, from Dr. Günther's figure and description in the Ann. \& Mag. Nat. Hist. for $24^{*}$ 
December 1889 , pp. 415-417, I identify as that of a Chimcera, probably Chimcera monstrosa, L. It is a little over 9 inches long, and, excepting for its larger size, in every other respect corresponds identically with that description.

\section{Order A CA N THOP T E R YGII. \\ Family Pediculati. \\ Dibranchus, Peters.}

2. Dibranchus micropus, Alcock.

Dibranchus micropus, Alcock, Ann. \& Mag. Nat. Hist., July 1891, p. 25, pl. vii. fig. 2 (ventral fins too large).

One specimen from Station 128, 902 fath.

In this specimen the mouth is, in proportion, a little larger than it is in the type specimen taken last year in 240-276 fathoms, and the teeth are so minute, cspecially those in the premaxillary, as to be almost indistinguishable. The subopercular spine is large and complex.

It is interesting to find this species, indisputably groundliving, ranging from 240 to 902 fathoms.

\section{Order A N A A N T H I N I. \\ Family 0phidiidæ. \\ Group $B$ ROTULINA. \\ Paradicroliene, Alcock. \\ 3. Paradicrolene multifilis, Alcock.}

Paradicrolene multifilis, Alcock, Ann. \& Mag. Nat. Hist., Nov. 1889, p. 387 , and July 1891 , p. 32 .

Several specimens, of both sexes, from Station 130, 281 to 258 fathoms.

In young individuals the lower (free) rays are very much less clearly separated from the rest of the fin and from each other than in adults.

Lamprogrammus, Alcock.

4. Lamprogrammus fragilis, sp. n.?

B. 8. D. circ. 90 . A. circ. 75 . C. 8 ? P. 17. V. 0.

Differs from Lamprogrammus niger (Alcock, Ann. \& Mag. Nat. Hist., July 1891 , p. 33 , fig. 2) only in the following 
particulars :-(1) the preoperculum is armed at its angle with three weak spines; (2) the length of the snout is barely twice the diameter of the eye, which is nearly one sixth the length of the head; (3) the length of the maxilla is not quite half that of the head; (4) the length of the trunk is hardly equal to that of the postrostral portion of the head; (5) the pectorals are large and long, reaching as far as the anal fin, but with regard to this difference it is as well to remark that the pectorals in our specimens of $L$. niger are much broken.

There is a small thick-walled air-bladder.

Colour jet-black.

A single male specimen, 19 inches long, from Station 133, 678 fathoms.

It is possible that this species may be the male of Lamprogrammus niger, of which three female specimens were obtained last year; and though it would be premature to decide that this is the case, yet the belief of its probability must be here recorded.

\section{Hephthocara, gen. nov.}

Head large, with thin, smooth, uncrested bones, scaleless. No armature but a weak opercular spine. Body compressed, tapering, covered with deciduous cycloid scales. Eye moderate. Snout not overhanging the jaws. Mouth with obliquely ascending eleft, and with the lower jaw prominent. Villiform teeth in the jaws, palatines, and vomer. No barbel or hyoid filaments. Gill-openings wide; gill-membranes separate; four gills, no pseudobranchiæ; eight branchiostegals. Lateral line indistinguishable. Vertical fins confluent; pectoral fins entire; no ventral fins.

\section{Hephthocara simum, sp. n. (PI. XVIII. fig. 1.)}

Head of great relative size, deep, broad, and much inflated posteriorly, falling steeply in front to the small abruptly narrowed and depressed up-tilted snout; its length is about two ninths of the total without the caudal, and its greatest height posteriorly is a little over three quarters, and its greatest breadth a little over half, its length. 'The cranial bones are wafer-like and quite smooth, the only armature of the head being a flat spine at the upper part of the operculum.

The small snub snout, the end of which is formed by the projecting mandible, exceeds in length the width of the interocular space, this being about twice the major diameter of the 
deep-set eye, which again measures about one eighth the length of the head. The nostrils are inconspicuous and are situated one in front of the angle of the eye, the other at the tip of the snout.

Mouth large, with its cleft obliquely ascending, and with the mandible projecting beyond the thin broad maxilla, which last in length is a little more than half that of the head. Villiform teeth in broadish bands in the premaxillæ and mandible, and in very narrow bands on the palatines and expanded head of the vomer.

Muciparous system of mandible and preoperculum highly developed.

Gill-openings extremely wide, the gill-membranes being entirely separated from each other and from the isthmus; eight branchiostegal rays; four gills, with narrow laminæ and short papilliform gill-rakers; pseudobranchiæ absent.

'The head is covered with a delicate scaleless skin, which in life, owing to an extraordinary storage in and beneath it of mucus, forms a uniformly thick velvety cap. The nape and body are covered with membranous, deciduous, cycloid scales, of moderate size. No lateral line can be distinguished.

The fin-rays are all extremely delicate; the dorsal fin, which begins about a snout-length behind the level of the gill-opening, and the anal, which begins nearly a head-length behind the same level, are confluent with the caudal at its base. The narrow pointed pectorals are a little longer than the rostrorbital portion of the head. There are no traces of ventrals.

Stomach subsiphonal and without any cacal sac; no pyloric caca; a large thin-walled air-bladder.

Colour uniform dark sepia; fins black.

An immature specimen, 8 inches long, from Station 128, 902 fathoms.

I have not attempted to give the radial formula, as no accurate determination could be made without sacrificing the unique specimen.

Hephthocara is to be classed with Bellotia, Giglioli (Zool. Anzeiger, vi. Jahrg., 1883, p. 399), Alexeterion, Vaillant (Expéd. S'ci. du 'Travailleur' et du 'Talisman,' Poiss. p. 282), and Lamprogrammus, mibi, with all of which it agrees in the absence of ventral fins. From Bellotia and Alexeterion it differs, as these differ from one another, in the nature of the integument and in the nature of the dentition; it is further distinguished from Bellotia by its more numerous branchiostegal rays, by its small, almost rudimentary gill-rakers, by the absence of a lateral line, and by the rela- 
tive proportions of the trunk; and from Alexeterion by this last character and by the well-developed eyes. It must be borne in mind, however, that both Bellotia and Alexeterion were described from specimens under 50 millin. in length, a consideration which may well lead us to doubt the ultimate correctness of separating these three closely allied forms. Lamprogrammus, with its crested scaly head, its Halosauruslike lateral line, and its very differently arranged viscera, is, I venture to think, quite distinct both from Hephthocxra and from the other two genera of the alliance.

\section{Family Macruridæ.}

Macrurus, Bloch. Subgenus Macnurus, Günther.

6. Macrurus investigatoris, Alcock.

7. Macrurus semiquincunciatus, Alcock.

8. Macrurus macrolophus, Alcock.

Specimens of all of the above, which were originally described in the Ann. \& Mag. Nat. Hist. for November 1889, were dredged at Station 131, 410 fathoms.

\section{Macrurus Hextii.}

Macrurus Hextii, Alcock, Ann. \& Mag. Nat. Hist., Oct. 1890, p. 299.

A large female specimen, nearly 23 inches long, from Station 122, 865 to 880 fathoms.

The ovaries are of moderate size and quite smooth and homogeneous on section.

A transverse section of an ovary, magnified, shows an external investment, about 1.20 millim. thick, of compact fibrous tissue, in which numerous large blood-vessels are imbedded, giving off internally fine loosely woven dissepiments to carry small blood-vessels into the substance of the ovary, the developing ova in their follicles being clustered round these dissepiments like grapes on a bunch. There is thus, even at this early stage, almost no interfollicular stroma.

The ova in the sections examined vary in diameter from .05 to .5 millim., the most usual diameter being .25 millim.

Such an ovum lies in a follicle which it completely fills. The wall of the follicle is formed by a few fine fibres of connective tissue lined internally by a layer of very small flattened hexagonal cells, which in transverse section look like 
352 Mr. A. Aleock on Indian Bathybial Fishes.

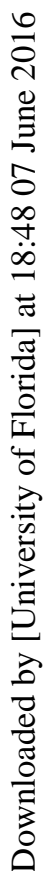

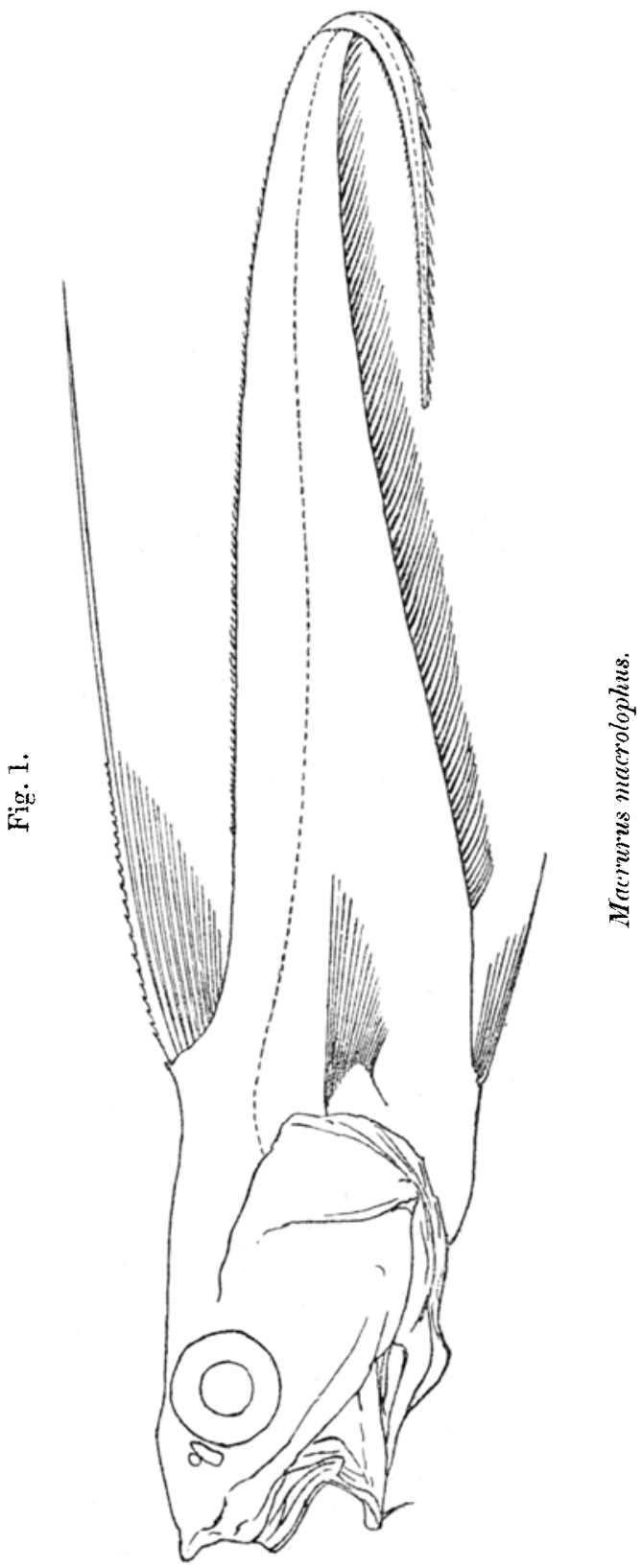


cubes. The ovum is defined by an egg-membrane of some thickness, which often shows as a broad double-contoured wavy line. The contents of the ovum are granular, and, as seen in transverse section, the granules have a tendency, best marked in the large ova, to arrange themselves in concentric circles round the nucleus, the innermost circle forming a tine darkly staining (carmine) circum-nuclear chain. The nucleus is a large circular or oval vesicle, sharply bounded by a very distinct nuclear membrane, and having a diameter nearly half that of the entire ovum. It contains from twenty to thirty, and sometimes even more, large vesicular nucleoli, deeply staining with carmine, which, in a view of a transverse section, have an inclination to fall in a ring round the periphery of the nucleus. In the largest ova the nucleoli are not so numerous and have no particular arrangement.

In the very smallest ova the follicular epithelium is not distinguishable.

\section{Macrurus Wood-Masoni, Alcock.}

Macrurus Wood-Masoni, Alcoek, Ann. \& Mag. Nat. Hist., Oct. 1890, p. 301, and Ang. 1891, p. 121.

In the original description of the type, which had suffered some denudation, it is stated that the lateral line runs $4 \frac{1}{2}$ rows of scales beneath the first dorsal instead of $5 \frac{1}{2}$, as all our later specimens show. In all thesespecimens, moreover, the terminal portion of the gut forms a wide pouch, which in one instance recalls the external appearance of the so-called "colon" of the Elasmobranchs.

Several specimens from Station 128, 902 fathoms, and Station 135, 559 fathoms.

Batimgaues, Günther.

\section{Bathygadus cottoides, Günther?}

P Bathygadus cottoides, Günther, 'Challenger' Deep-sea Fishes, p. 154, pl. xlii. fig. A.

I refer with some hesitation to this species a small specimen from Station 131, 410 fathoms, which agrees in most essential particulars with Dr. Günther's description. 'The only apparent divergences of the specimen are (1) that the eye is relatively larger, and (2) that the first dorsal ray is a little prolonged, both of which differences would become less and less marked with the advance of age. 


\title{
Family Pleuronectidæ.
}

\author{
Aphoristia, Kaup. \\ 12. Aphoristia Wood-Masoni, Alcock.
}

Aphoristia Wood-Masoni, Alcock, Journ. As. Soc. Beng. vol. lviii. pt. ii., 1889, p. 294, pl. xvii. fig. 1 (outline).

Three fine specimens from Station 132, 475 fathoms.

The number of dorsal rays ranges from 90 to 98 , and of anal from 78 to 84 .

\section{Order PH Y S OS T OMI. \\ Family Sternoptychidæ.}

Gonostoma, Rafinesque.

\section{Gonostoma elongatum, Günther.}

Gonostoma elongatum, Günther, 'Challenger' Deep-sea Fishes, p. 173, pl. xlv. fig. B; Alcock, Ann. \& Man. Nat. Hist., Aug. 1891, p. 127.

A fine female specimen, $7 \frac{3}{4}$ inches long, was taken at Station 127, 1200 fathoms. From it we can confirm the observation that scales are absent in this species. From the fact that this individual was not only alive and active when taken from the trawl, but remained alive for about a quarter of an hour after it was brought on board, I think we may doubt whether it came from any great depth. No display of luminosity was observed, though it was watched for.

The ovaries in this specimen are long narrow tubes, extending throughout the length of the abdomen, in which the developing ova form a long string thrown into deep close pleats or lamina. In a magnifed transverse section of an ovary, stained with carmine, very little stroma is seen except where the ovarian blood-vessels course (longitudinally) along the tube; no follicular epithelium is visible; each ovum is bounded by a fine egg-membrane, within which the eggsubstance forms a thick ring round the large nucleus, the egg-substance being granular and studded with large vesicles which do not take the stain; the nucleus is very definitely limited, although no membrane can be distinguished, and it stains so deeply that sometimes no further details can be made out, though generally from one to six even more deeply. stained nucleoli are seen; its diameter is about half that of the whole ovum.

The stomach of Gonostoma elongatum, as investigated microscopically by transverse sections through its wall, has 
the submucous coat most remarkably developed, and with a structure like that of the cortical substance of mammalian lymphatic gland; it consists of a very perfect and regular network of fine connective-tissue trabecula, the long narrow meshes of which are crowded with leucocytes; a dense layer of pigment bounds the submucosa externally.

\section{Chauliodus, Bl. Schn.}

\section{Chauliodus Sloanii, Bl. Schn.}

Several specimens were obtained in the Laceadive Sea.

The stomach of Chauliodus, like that of Gonostoma, is remarkable for the great development of its submucous coat, which, in transverse section under the microscope, is seen to be formed of a very regular and perfect connective-tissue network, of which the meshes are filled with deeply staining (carmine) leucocytes imbedded in a granular matrix-a structure not at all unlike that of the cortex of mammalian lymphatic gland. In many sections the larger septa, by whose regular ramifications the network is formed, pass straight through the muscular coat to the external fibrous coat of the viscus.

\section{Chauliodus pammelas, sp. $\mathbf{n}$.}

\section{B. $16 . \quad$ D. 6 . A. $12 . \quad$ V. 7. P. 11-12.}

Closely resembles Chauliodus Sloanii, from which it differs only in the following points:-(1) The body is much deeper, and has in life well-markedly convex dorsal and ventral profiles; (2) the eye is relatively much larger, its diameter being equal to the length of the snout measured to the extremity of the outstanding mandibular symphysis, or two sevenths the length of the entire head, or nearly two thirds of the length of the longest mandibular fang; (3) the skin is apparently naked, and though there are rhomboidal and hexagonal pits, these contain no silvery scale-like plates, but only a central "luminous" spot, and the entire body is covered in life with a thick sheet of iransparent mucoid tissue traversed by capillary blood-vessels; (4) the ventral "luminous organs" are less numerous and very much smaller, and the suborbital organ, which in $C$. Slounii is so conspicuous, is reduced to a minute point distinguishable only with a lens; (5) the first ray of the dorsal fin is relatively longer; $(6)$ the body, fins, and iris are uniform jet-black.

A very fine specimen, 10 inches long, from Station 126 , 1370 fathoms. 


\section{Family Scopelidæ.}

\section{Harpodon, Le Suer.}

16. Harpodon squamosus, Alcock.

Ha'podon squamosus, Alcock, Ann. \& Mag. Nat. Hist., Aug. 1891, p. 127.

'This interesting species seems characteristic of the Bay of Bengal, between 200 and 300 fathoms.

\section{Bathypterois, Günther.}

17. Bathypterois insularum, sp. $\mathrm{n}$.

B. $13-14$.
D. $12-13$.
A. 10.
P. 2/12-13. V. 9 .
L. lat. 48-51. L. tr. 13 .

Body elongate, its height a little more than halt the length of the head, which is about one fourth of the total without the caudal. The snout, which has the typical duck-bill shape, is in length a little more than one third the length of the head. T'he very small eyes are not quite a snout-length apart. There is nothing peculiar about the mouth, but there are no teeth on the vomer. The branchial structures are identical with those of other species of the genus. The body and the head, except the jaws and snout, are covered with thin deciduous cycloid scales.

The dorsal fin begins half a snout-length behind the base of the ventrals, and the anal immediately behind the vertical through the last dorsal ray; there is a small adipose "fin" nearly midway between the dorsal and the base of the caudal. The two uppermost pectoral rays are intimately coherent in their basal half and reach at least as far as the adipose dorsal; the other pectoral rays, which are slender and rigid, reach at least as far as the vent. The ventral fins are very large, their two outermost rays, which are very stout and stiff, reach, when laid back, within a snout's length of the base of the caudal, their tips being filiform. The two or three lowermost rays of the forked caudal are prolonged, their length being at least one third that of the rest of the body.

Colour black ; fins hyaline grey.

Length $5 \frac{1}{2}$ inches.

'Two adult females with gravid ovaries from Station 121, 1140 fathoms. 
Alepocephalus, Risso.

18. Alepocephalus Blanfordii, sp. $\mathrm{n}$.

\section{B. 6. D. 16. A. 17. P. 11. V. 6-7. L. lat. circa 70. Pyloric crea 12.}

Length of head one third, height of body two elevenths, of the total without the caudal.

The length of the obtusely-pointed depressed snout is barely greater than the diameter of the huge orbit, or two sevenths of the length of the head.

The eyes are hardly half a diameter apart, with the large nostrils placed close together in front of their angle.

The mouth-cleft is almost horizontal, and the upper jaw, which reaches just beyond and rests upon the anterior border of the orbit, completely encloses the mandible on all sides; a row of fine teeth in each jaw and on each proninent palatine.

Gill-openings very wide, the gill-membranes entirely separate and not overlapping; the branchiostegal rays are but little concealed by the opercalar bones, and the whole gill-cover is clothed by a continuation of the thick scaleless skin that covers the head; gill-rakers numerous, close-set, broadly lanceolate, acute; pseudobranchiæ large and coarse.

Body covered with thick deciduous cycloid scales; a scale from the abdomen is nearly 5.5 millim. in the horizontal and 5 millim. in the vertical diameter. The dorsal and anal fins, which are similar in form, equal in extent, and opposite, lie well within the posterior third of the body (measured without the caudal); the caudal is deeply forked, with many rudimentary rays at its base. The ventrals arise almost in the middle of the body, nearer to the anal than to the pectorals.

Stomach siphonal; a row of fourteen very large and long pyloric cæca embraces its pyloric moiety; the intestine, which when unravelled is about twice the entire length of the fish, is arranged as in Alepocephalus bicolor (Ann. \& Mag. Nat. Hist., Aug. 1891, p. 134), but the wall of the coiled up small intestine is much thicker, and the straight binder gut is held by a stout mesentery.

Colour : head and fins black; body lavender-grey.

A fine male, a little over 14 inches long, from Station 128, 902 fathoms.

The straight large gut in this species, as in Alepocephalus bicolor, is remarkable for the great thickness of its wall and for its contracted lumen; only in the present case, although the circular muscular coat is conspicuously thick, it is not 
this but the highly glandular mucous coat that contributes most to the thickness of the wall. The great development of the glands of the mucosa, which are compact little branching follicles, is in marked contrast to $A$. bicolor, where the mucous membrane consists of simple columnar epithelium. The loose submucous coat is honeycombed with (lymphatic?) channels and crowded with leucocytes; but the large pigmented granular corpuscles which were so numerous in $A$. bicolor are here few in number.

The small intestine at its duodenal end and the pyloric cæca appear, in transverse sections, to be identical in structure. In both the mucous membrane is thrown into apparently permanent longitudinal folds, and contains in its depth a regular series of glands formed by a cluster of loculi opening into the bottom of a long vestibule which would serve as a duct. Microscopic cylinders of glandular substance, which in stained sections has exactly the appearance of mammalian pancreas, run in the mesentery, parallel with the pyloric cæca and in contact with them.

\section{Alepocephalus edentulus, sp. n. (Pl. XVIII. fig. 2.)}
B. 6. D. 29.
A. 35 .
V. 6
P. 9 .
I. lat. circa 50 . L. tr. 15 .

The length of the head is a little more than one fourth, and the height of the much compressed body nearly one fifth, of the total with the caudal included. The blunt snout is barely equal in length either to the width of the interorbital space or to the diameter of the eye, which is very nearly two ninths the length of the head. The mouth-cleft is almost horizontal, the jaws are even anteriorly, and the maxilla reaches considerably behind the vertical through the centre of the eye. Minute teeth occur in a row in the premaxillæ and mandibles, and there are a few inconspicuous and deciduous teeth on the prominent edges of the palatines only.

Gill-openings very wide, the gill-membranes being attached to the isthmus only quite anteriorly; gill-rakers conspicuous on all the branchial arches, and, to the number of about tweive in the middle of the first arch, long and setaceous; pseudobranchiæ small. Head covered with a velvety scaleless skin; body with scales that are so deciduous as to have entirely disappeared, leaving only imprints.

The long anal fin begins an eye-length behind the middle of the body, measured without the caudal, and the shorter dorsal arises in the vertical through the sixth or seventh anal 
ray; the caudal is completely divided down to its base into two long feathery lobes. The small ventrals, which arise midway between the base of the pectoral and the origin of the anal, reach rather more than halfway to the latter point.

Stomach siphonal; a row of four stout pyloric cæea; intestine slightly coiled, with its terminal end enlarged and thick-walled.

Colours: head and eyes jet-black; body and fins greyish black.

A single specimen (a mature male), nearly 7 inches long, from Station 132, 475 fathoms.

\section{Xenodermichthys, Günther.}

20. Xenodermichthys Guentheri, sp. n. (Pl. XVIII. fig. 3.)
B. 6 .
D. circa 15 .
A. circa 14.
V. 6? P. 5?

Body elongate, compressed, covered with a thick scaleless, longitudinally-wrinkled, black skin, in which scattered granular yellowish-coloured nodules are imbedded. The dorsal and anal profiles are symmetrically similar in life. The length of the head is slightly over two sevenths and the height of the body immediately benind the gill-opening slightly under one sixth of the total without the caudal.

The obtuse snout, surmounted by an acutely-pointed tubercle which projects from the prominent symphysis of the lower jaw, is not quite equal in length to the diameter of the circular eye. The eyes, which in life encroach upon the dorsal profile, measure between one fourth and two sevenths of the length of the head, and are about two thirds of a diameter apart.

The mouth-cleft is oblique, and the jaws are even in front, except for the symphysial tubercle on the mandible. The premaxilla, which form on each side nearly one half the extent of the margin of the upper jaw, are armed with a row of minute close-set teeth, as are also the maxillæ, which have the typical Alepocephaloid structure and which reach to the vertical through the posterior border of the orbit, and the broad scapula-shaped mandible; no teeth on the palatines or vomer.

The gill-cleft is extremely wide, extending forwards almost to the mandibular symphysis and upwards almost to the posttemporal region; the opercle appears to be perfect, and, together with the branchiostegal rays, is enveloped in a thick membranous skin, as in Alepocephalus; four gills, with 

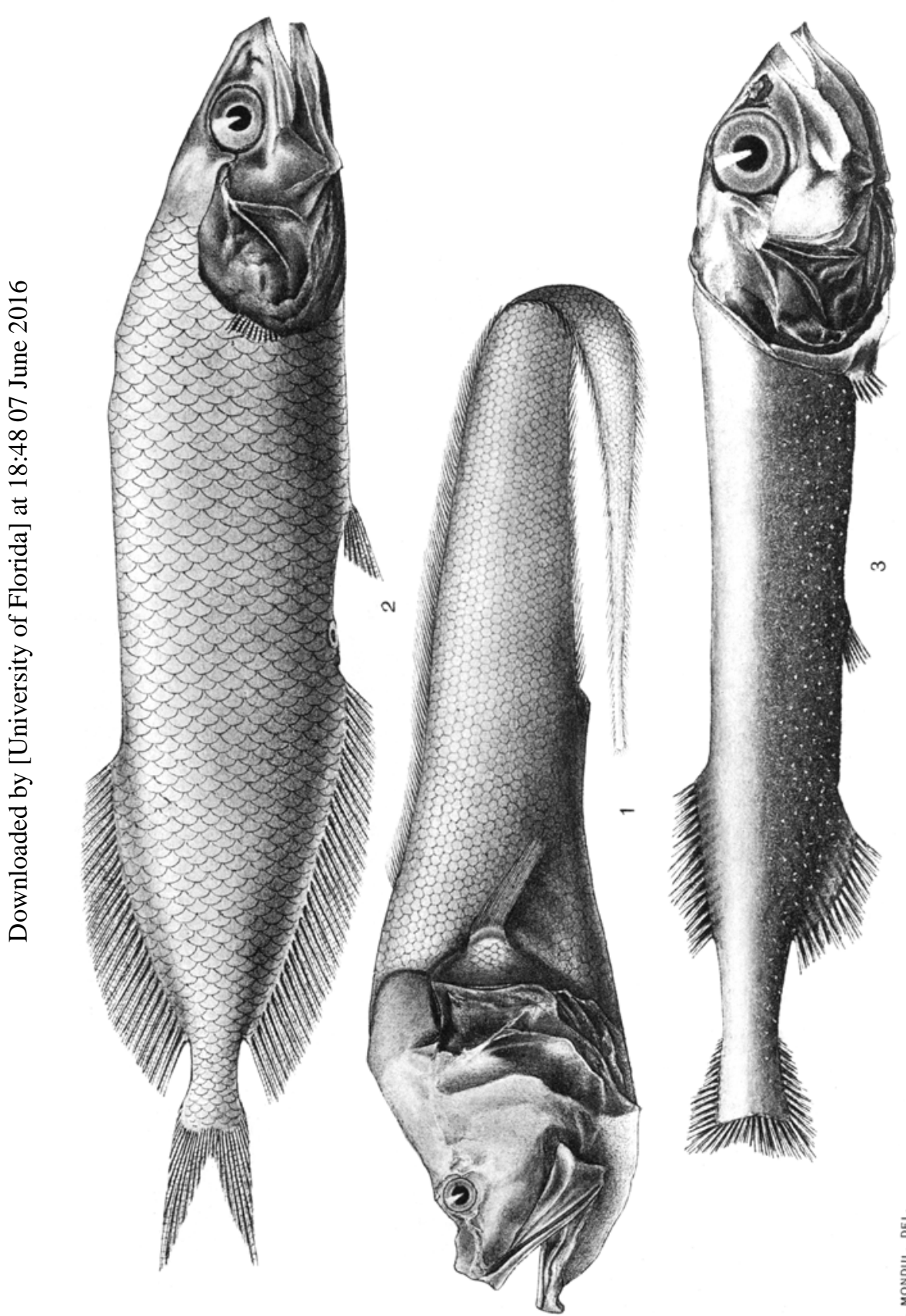

六

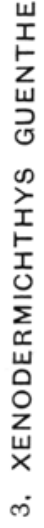

गُ

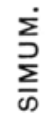

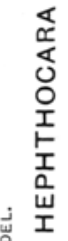


numerous long close-set gill-rakers on the first arch; pseudobranchia present.

No lateral line can be distinguished.

The dorsal and anal fins, which are equal, opposite, and similar, lie in the posterior third of the body, and approach within an eye-length of the long series of rudimentary rays that form the base of the deep-forked caudal. The ventrals lie well within the posterior half of the body, and the pectorals arise on the ventral profile, almost in the same horizontal line with the ventrals.

The stomach is siphonal and its pyloric end is embraced by a row of seven or eight cacal appendages, the posterior six of which are relatively enormous; the intestine has an anterior much coiled portion and a hinder portion which passes perfectly straight backwards, much as in Alepocephalus bicolor and $A$. Blanfordii, to its orifice just in advance of the posterior third of the body.

Colour uniform jet-black.

One specimen, a mature female about 6 inches long, from Station 133, 678 fathoms.

The ovaries are distended with ova and terminate in a short, broad, straight oviduet, which opens by a broad pore behind the vent. The ova are of two sizes, some few being about as big as a pin's head, but the great majority being between 2 and 3 millimetres in diameter-a size truly enormous for such a small fish.

Five of the larger eggs were examined microscopically, and in every instance the large vesicular nucleus, with its large vesicular nucleolus, was found to lie, surrounded by a

Fig. 2.

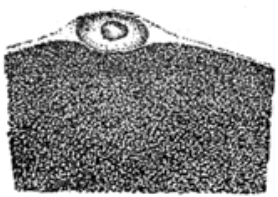

Segment of the animal pole of an ovum of Xenodermichthys Guentheri, $\times 42$, showing the germinal disk with its large vesicular nucleus lying upon, and quite isolated from, the granular yolk.

thin but extended envelope of clear protoplasm, quite outside the granular mass of yolk, at one pole of the egg. In one case a linear series of such large nucleated vesicles (blastomeres?) was found lying imbedded in a thin disk of protoplasm at one pole, just as if the segmentation of the fertilized 
ovum had begun. The nucleus, in short, with the clear protoplasm that surrounds it; forms a germinal disk lying upon but quite separate from the yolk, as has already been observed in many other 'l'eleostean ova, and as has been commented upon by Mr. E. E. Prince in a paper upon "The Signifieance of the Yolk in the Eggs of Osseous Fishes" (Ann. \& Mag. Nat. Hist., July 1887, pp. 1-8, pl. ii.), in which will be found numerous references to the work of previons observers.

In general external form Xenodermichthys Guenther $i$ is not at all unlike Xenodermichthys socialis, Vaillant (Expéd. Sci. du 'Travailleur' et du 'Talisman,' Poiss. pp. 162-165, pl. xiii. fig. 1). Its form, too, strongly reminds one of certain Sternoptychoid types, e. g. Gonostoma, and even more, as Dr. Günther has already remarked of the type of this genus, of some of the Stomiatidx.

The details of its internal (visceral) structure repeat remarkably what I have myself observed in several Alepocephaloids, namely Alepocephalus, Bathytroctes, and Narcetes.

\section{LePTODERMA, Vaillant.}

\section{Leptoderma macrops, Vaillant.}

Leptoderma macrops, Vaillant, Expéd. Sci. du 'Travailleur' et du 'Talisman,' Poiss. p. 166, pl. xiii. fig. 2.

A magnificent quite perfect specimen, $8 \frac{3}{4}$ inches long, from Station 134, 753 fathoms.

Over the intensely black cutis there stretches, from the tip of the snout to the tip of the tail and investing all the fins, a thick velvety opaline-grey epidermis, which much resembles that covering the head of Aulastomatomorpha (Ann. \& Mag. Nat. Hist., Oct. 1890, p. 307, and Jan. 1891, p. 10). It appears probable that this epidermis is luminous in function, for when the fish was removed, freshly dead, from the trawl, and put into a pail of muddy sea-water under shade, its form could be distinctly made out glimmering, ghost-like, at the bottom of the pail. In the fresh state the epidermis is freely movable over the black skin beneath, but in spirit it contracts and becomes firmly adherent to the underlying tissues. Examined under the microscope nothing further can be seen than branched black and reddish-yellow pigment-cells.

There is a distinct lateral line, consisting of a single row of large pores, extending from the occiput to the base of the caudal.

The attenuated caudal is forked. Ann. \& Mag. N. Hist. Ser. 6. Vol. x. 
Small pseudobranchiæ consisting of three or four pinnules are present.

\title{
Family Halosauridæ.
}

\author{
Halosaurus, Johnson.
}

22. Halosaurus parvipennis, sp. $\mathrm{n}$.

B. 13 . D. $9 . \quad$ P. $12-13$. V. 1/9. L. tr. $\frac{\frac{10}{\mathrm{~s}}}{\mathrm{~s}}$.

The length of the head is a little over one eighth of the total, or about two fifths the length of the rest of the trunk.

The length of the snout, of which nearly half is preoral, is two fifths that of the head, or equal to that of the postocular portion of the head. The eyes are separated by one fourth of a diameter only, their diameter being one half the length of the snout. The weak maxillary does not quite reach to the vertical through the anterior border of the orbit. Villiform teeth in bands in the jaws and palatines and in a narrowed band on the pterygoids.

Gill-rakers distant, short.

The dorsal fin arises from a scaly base about an eye-length behind the ventrals, which arise, also from scaly bases, a head-length and a quarter behind the gill-opening; about half a head-length behind the dorsal fin is an erectile scale as long as the eye. The weak, narrow, pointed pectorals are but little longer than the snout.

The scales of the lateral line are much more adherent than those of the rest of the body, though but little larger.

There are eight or nine small pyloric appendages in a row embracing the ascending limb of the siphonal stomach.

Colours : light sepia-brown, fins darker; opercles silvery; throat and branchiostegal membranes black.

A female, about 15 inches long, with gravid ovaries, from Station 122, 865 to 880 fathoms.

\section{Family Murænidæ.}

Congromurana, Kaup.

23. Congromurcena longicauda, Alcock.

Congromurana longicauda, Aleock, Ann. \& Mag. Nat. Hist., Dec. 1889, p. 455 .

This species seems to be characteristic of the Bay of Bengal between 200 and 300 fathoms. 


\section{UROCONGER, Kaup.}

\section{Uroconger vicinus, Vaillant.}

Uroconger vicinus, Vaillant, Expéd. Sci. du 'Travailleur' et du 'Talisman,' Poiss. p. 86 , pl. vi. fig. 1.

A large female, 25 inches long, with gravid ovaries, from Station 132, 475 fathoms.

The stomach in this specimen has a large cæcum, a much constricted pylorus, and a mucous membrane of two entirely different kinds, that in the anterior half being of an almost horny hardness, while that in the posterior half is soft and glandular.

In vertical longitudinal sections of the stomach-wall, carried through the abrupt line of demareation between the two differing regions of mucous membrane, examined under the microscope, the following structure is seen :-

(1) Common to both regions of the stomach: $(a)$ an external thin fibrous coat, one fortieth to one sixth of a millimetre thick, with many longitudinal bundles of muscular fibres and large blood-vessels; (b) a very compact thin coat of transverse muscular fibres, about one eighth of a millimetre thick ; (c) another very compact layer of longitudinal muscular fibres, about one seventh of a millimetre thick; $(d)$ a very thick $\left(\frac{3}{4}-1 \frac{1}{8}\right.$ millimetre) submucous coat made ap of a loose meshwork of branching and anastomosing small-nucleated cells, the meshes being filled with lymphoid cells; this coat also contains many blood-vessels, which frequently traverse in their course large, compact, sharply-circumscribed nodules of lymphoid tissue, and a great many branching pigment-cells.

(2) The mucous membrane of the anterior part, which is about one eighth of a millimetre thick, appears at first like a superficial layer of pure fibrous tissue; but good sections show that it consists of a stratified epithelium with its constituent cells compressed somewhat as in the horny layer of the human epidermis. These compressed (horny) cells, however, are not flattened into plates to form a smooth surface, but are angularly concreted to form a broken rough surface. Beneath the superficial horny layer are several rows of cells of which the granular protoplasm seems to be fused into a solid mass, leaving only the nuclei distinct; and beneath this again comes fibrous tissue gradually passing into the loose submucosa.

(3) The boundary-line between the anterior horny mucosa and the posterior soft mucosa is very abrupt, and in every section there is seen a conspicuous thickening of the sub- 
mucous coat at the expense of both the mucous and the muscular coats. The mucous coat is made up of the compact ramifications of an acino-tubular gland lined with granular, large-nucleated, cubical epithelium.

(4) The mucous membrane of the posterior part, which is rather over one fourth of a millimetre thick, is formed entirely of long tubular glands packed close together, side by side, at right angles to the surface. These glands, which much resemble mammalian gastric glands, are lined with a granular cubical epithelium having large prominent vesicular nuclei; they have broadish mouths, and in their deepest third they end by subdividing into two or three long sinuous branches, which lie in a plane parallel to that of the rest of the gland.

\section{Coloconger, Alcock.}

25. Coloconger raniceps, Alcock.

Coloconger raniceps, Alcock, Ann. \& Mag. Nat. Hist., Dec. 1889, p. 456.

This species, like the next mentioned, seems to be characteristic of the Bay of Bengal between 200 and 400 fathoms, occurring in almost every haul.

\section{Nettastoma, Rafinesque.}

26. Nettastoma treniola, Alcock.

Nettastoma teniola, Alcock, Ann. \& Mag. Nat. Hist., August 1891, p. 135.

I leave this species for the present in the genus Nettastoma. The tissues are very delicate, and though in some specimens the air-bladder is very distinct, in others it is hard to distinguish.

\section{Gavialiceps, Wood-Mason (MS.).}

\section{Gavialiceps microps, Alcock.}

Gavialiceps microps, Alcock, Ann. \& Mag. Nat. Hist., Dec. 1889, p. 461 .

Two good specimens were obtained, one, 15 inches long, from Station 126, 1370 fathoms, the other, 13 inches long, from Station 128, 902 fathoms.

From an examination of these specimens in the fresh state, the following remarks must be added to the description of the mutilated and distorted (type) spirit-specimen :-

The long lash-like tail is between two and a half and two 
and three quarter times the length of the combined head and trunk. The head, about half of which is formed by the long needle-like beak, is at least twice the length of the trunk proper ; its posterior half is broad, deep, and subquadrangular. Eyes minute, subcutaneous, without any orbital fold. The maxillary teeth are arranged in a single row, and diminish in size but increase in number from behind forwards: the vomerine teeth posteriorly are long and sharp and are disposed in a long, close-set, comb-like series; anteriorly they form a fine rasp-like band: in the mandible a row of large distant needle-like teeth stands up from an uneven band of small denticles. Gill-openings close together, wide. The scaleless integument is thin and deciduous and thickly enveloped in mucus; no lateral line is apparent. The dorsal fin is feebly developed, and, indeed, hardly distinguishable. The pectoral fin is represented by an inconspicuous clavicular knob, without any rays.

The abdominal cavity extends at least halfway along the tail. The siphonal stomach, which has its pyloric end long, tapering, and much constricted, leads into a widely expanded duodenum, which, in the single specimen dissected, is furnished with a small diverticulum near the pylorus.

Colour uniform black, with a silvery sheen on the head.

This species is perhaps identical with Nemichthys infans, Vaillant (nec Günther), described and figured in Expéd. Sci. du 'Travailleur' et du 'Talisman,' Poiss. pp. 93 and 94 , pl. vii. fig. 1 , and there only doubtfully referred to Dr. Günther's type.

\section{EXPLANATION OF PLATE XVIII.}

Fig. 1. Hephthocara simum, sp. n.

Fig. 2. Alepocephalus edentulus, sp. $n$.

Fig. 3. Xenodermichthys Guentheri, sp. n.

\section{XLI.-On the Origin and Development of the Mammalian Phylum. By Dr. W. KükenthaL *}

[An Address delivered on May 28, 1892, in the Aula of the University of Jena, in accordance with the provisions of the Paul von Ritter foundation for phylogenetic zoology.]

OwING to the great division of labour which has taken place in our science, compelling the investigator to occupy himself with individual problems, it is well that we, for once allowing

* Translated from the 'Biologisches Centralblatt', xii. Bd. no. 13 (15̃th July, 1892), pp. 400-413. 